\title{
CHARACTERISTICS OF THE INCREASED ADRENOCORTICAL FUNCTION OBSERVED IN MANY OBESE PATIENTS*
}

\author{
David E. Schteingart and Jerome W. Conn \\ Department of Internal Medicine, \\ Division of Endocrinology and Metabolism and \\ The Metabolism Research Unit \\ University of Michigan, Ann Arbor, Mich.
}

Evidence of increased adrenal cortical function has been found in 30 to $60^{\circ}$ of obese people. In a group of obese individuals reported by us, ${ }^{1}$ those with increased adrenal cortical function manifested high urinary 17-hydroxycorticosteroids (17-OHCS) and high cortisol secretion rates (CSR). However, plasma 17-OHCS were lower than normal, and more of the secreted cortisol was converted to Porter and Silber chromogens (expressed as the ratio of CSR to U17-OHCS). Obese patients also present higher than normal cortisol turnover rates (TABLE 1).

In our study, neither the high urinary 17-OHCS nor the elevated CSR showed any correlation with either absolute body weight or with degree of obesity. Similarly, others ${ }^{2}$ have been unable to correlate the high urinary 17-OHCS and CSR with body surface in obesity.

From these and other studies, ${ }^{2,3}$ it appears that some obese patients exhibit a rapid rate of cortisol turnover, which is associated with an increased excretion of cortisol metabolites (measured as urinary 17-OHCS, 17-KS, or 17-ketogenic steroids). This should lead to lowering of the plasma 17-OHCS level and a compensatory feedback increase in cortisol secretion. The present study shows a relationship between excessive protein intake, increased glomerular filtration rate (GFR) and adrenal cortical overactivity in obesity.

\section{Materials and Methods}

The study includes 11 obese people, 3 male and 8 female, ranging in age from 16 to 42 years (mean $28 ; \mathrm{SD} \pm 8$ ). Eight of the 11 patients had elevated baseline urinary 17-OHCS; two had borderline and one other had normal baseline values.

Parameters of adrenalcortical function and cortisol metabolism were studied as follows:

(a) Urinary 17-hydroxycorticosteroids by the method of Porter and Silber. ${ }^{*}$

*This study was supported by Grants AM-05951 from the United States Public Health Service and 5M01-FR-42-04 from the Division of Research Facilities and Resources, National Institute of Health. 
(b) Urinary 17-ketosteroids by Chaney's modification of the method of Drekter, et al. ${ }^{5}$

(c) Plasma 17-OHCS by the method of Peterson. ${ }^{6}$

(d) Cortisol secretion rates (CSR) by our own modification ${ }^{1}$ of the isotope dilution method originally described by Cope and Black.

(e) Urinary free cortisol, isolated by chromatography from urine extracts. ${ }^{1}$

(f) Cortisol turnover rates (TR) by estimating the rate of disappearance of a tracer dose of ${ }_{4} \mathrm{C}^{14}$ cortisol injected intravenously and calculated as $\frac{0.693}{\mathrm{~T} / 2}(\mathrm{t} / 2$ : half-time disappearance of radioactive cortisol.)

Also measured were urinary and serum creatinine, endogenous creatinine clearance, and in several patients, inulin clearance.

All patients were studied on a metabolic ward. They were ambulatory, and their fluid intake was unrestricted and no attempt was made to keep electrolyte intake constant. All received a daily supplement of multivitamins

\begin{tabular}{l|c|c}
\hline \hline & Obesity & Normal \\
\cline { 2 - 3 } & 9.0 & 5.4 \\
U 17-0HCS (mg./24 hr.) & 24.5 & 15.0 \\
CSR (mg./24 hr.) & 14.4 & 25.2 \\
P1 17-0HCS ( $\mu$ gm./24 hr.) & 2.4 & 2.96 \\
CSR/U 17-0HCS & 0.0134 & .0087 \\
TR (K) & \\
\hline \hline
\end{tabular}

while on the experimental diets. They were studied: (a) on a weight maintaining diet of standard composition for 5-11 days; (b) on a protein free, 1000 calorie diet for up to 14 days; (c) on a high protein (225 gram) 1000 calorie diet, for up to 14 days. Some patients received the high protein diet before the one low in protein. Weight loss, ranging from 4 to $20 \mathrm{~kg}$. (mean 10.8; $\mathrm{SD} \pm 3.6$ ) occurred in every patient during the periods of caloric restriction.

\section{REsUltS}

\section{Effect of Protein and Calorie Restriction}

FIGURE 1 shows results of a representative study on an obese subject. This individual received a diet of average composition for 11 days. She was then switched to a protein free, 1000 calorie diet for 11 days, followed by a high protein, 1000 calorie diet for eight days. On calorie restriction, her initial weight of $115 \mathrm{~kg}$. declined to $109 \mathrm{~kg}$. Mean baseline values for urinary 17 OHCS (10.0 mgm. per 24 hours) and CSR (28.1 mgm. per 24 hours) were high. 


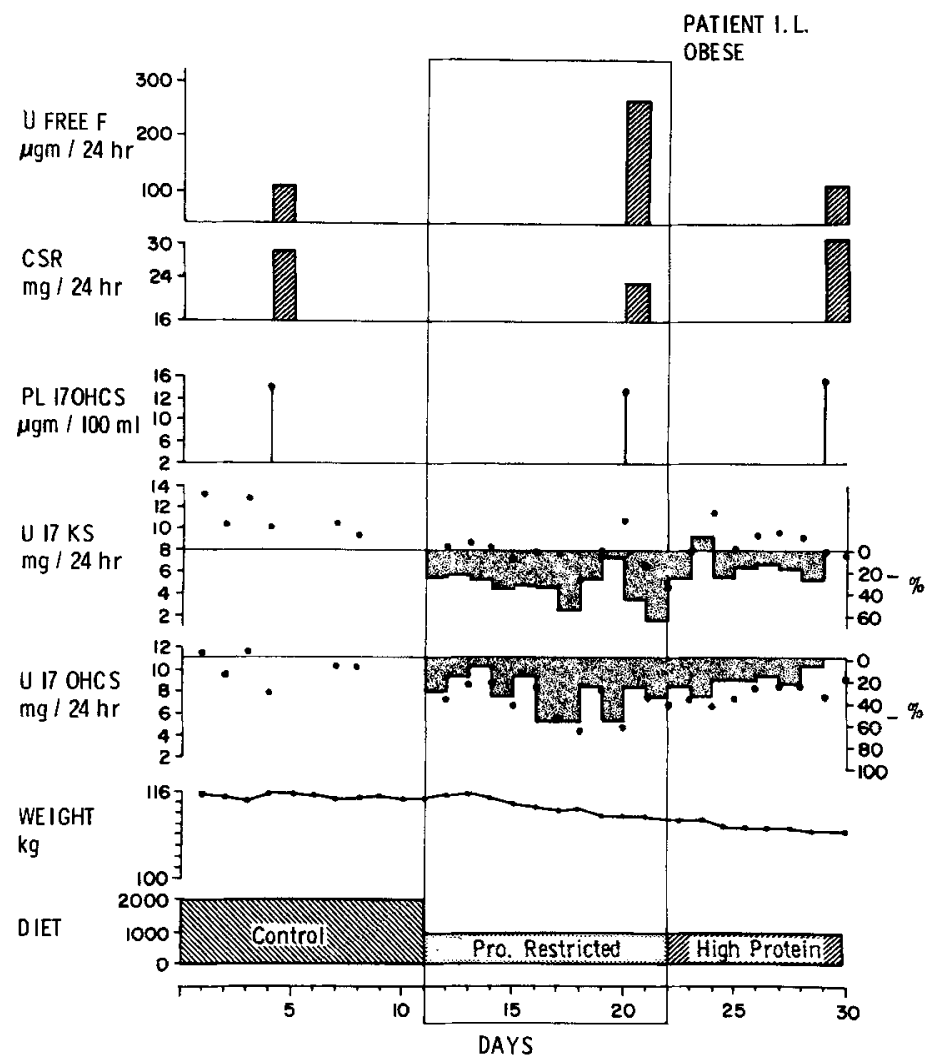

FIGURE 1. Representative study of the effect of protein and calorie restriction on an obese subject (I.L.).

Mean baseline values for urinary 17-KS (11.5 mgm. per 24 hours) and plasma $17-\mathrm{OHCS}$ level $(14.1 \mu \mathrm{gm}$. per $100 \mathrm{ml}$.) were normal. On protein restriction there occurred a decrease in the level of urinary $17-\mathrm{OHCS}$ and $17-\mathrm{KS}$, beginning within 24 hours. The maximal decrease in urinary 17-OHCS (58 per cent) occurred in seven days; in urinary $17-\mathrm{KS}$ ( 63 per cent), in 11 days. CSR decreased on the 10 th day of protein restriction to $23.5 \mathrm{mgm}$. per 24 hours. Plasma 17-OHCS level remained unchanged. Urinary free cortisol rose from 110 to $281 \mathrm{mgm}$. per 24 hours. On high protein intake, urinary 17-OHCS and 17-KS increased from those observed during the low protein period, but they were still below the levels on the control diet at the conclusion of the eight day study period. CSR, measured on the eighth day of high protein intake had risen to $31.4 \mathrm{mgm}$. per 24 hours, a value comparable to that of the control diet. Turnover rate of cortisol, estimated on the control diet was 0.0150 , a value higher than normal. On protein restriction it decreased to 0.0115 and increased toward the control value by the conclusion of the high protein intake, when it was 0.0133 (FIGURE 2). 
FIGURE 3 presents the results of a study on another obese subject. In this case, the high protein, 1000 calorie diet preceded the protein restricted 1000 calorie diet. The control diet was given for seven days; the high protein and the protein restricted diets for 14 days each. The weight declined from 93 to 84 $\mathrm{kg}$. on caloric restriction. Mean baseline urinary 17-OHCS (10.4 mgm. per 24 hours) was high; mean baseline urinary $17-\mathrm{KS}$ (9.4 mgm. per 24 hours) and mean CSR (20.6 mgm. per 24 hours) were normal. Plasma 17-OHCS levels were 21.9 and $54.9 \mu \mathrm{gm}$. per $100 \mathrm{ml}$. There was no significant change in the urinary level of $17-\mathrm{OHCS}$ and $17-\mathrm{KS}$ on high protein intake. Urinary creatinine, however, increased within 24 hours and remained higher than on the control period, throughout high protein intake. CSR increased to 31.3 and 24.2 mgm. per 24 hours and plasma 17-OHCS were slightly higher. On protein restriction there occurred again, a significant decrease in urinary 17-OHCS and 17 -KS which began within 24 hours. Urinary $17-\mathrm{OHCS}$ reached a maximal decrease ( 50 per cent) in 8 days and urinary $17-\mathrm{KS}$ ( 50 per cent) in 14 days. Urinary creatinine levels decreased significantly and remained low throughout protein restriction. CSR decreased to $17.9 \mathrm{mgm}$. per 24 hours. Plasma 17-OHCS were slightly lower than on the preceding diet. Urinary free cortisol did not change significantly on either diet. As in the previous study, the turnover rate of cortisol which was 0.0108 on the control diet decreased to 0.00787 on protein restriction (FIGURE 4).

Findings similar to these have been observed in all the obese patients which we have studied. There was a consistent decrease in the median (and mean) urinary 17-OHCS, 17-KS and creatinine levels, and in CSR on protein restriction. Lower turnover rates of cortisol occurred during the low protein period in eight of nine patients (FIGURE 5).

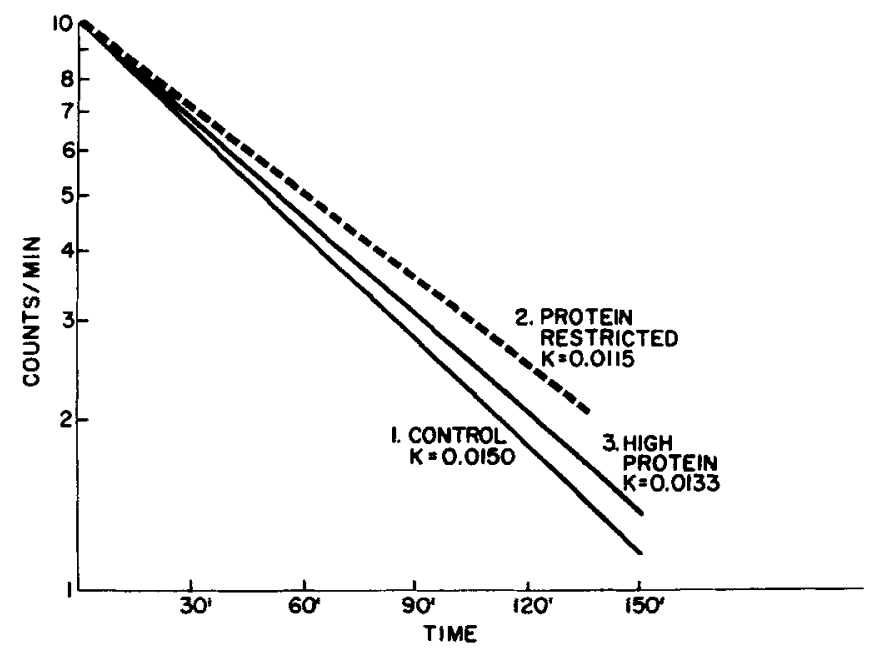

FIGURE 2. Change in cortisol turnover rate as influenced by diet (obese subject I.L.). 


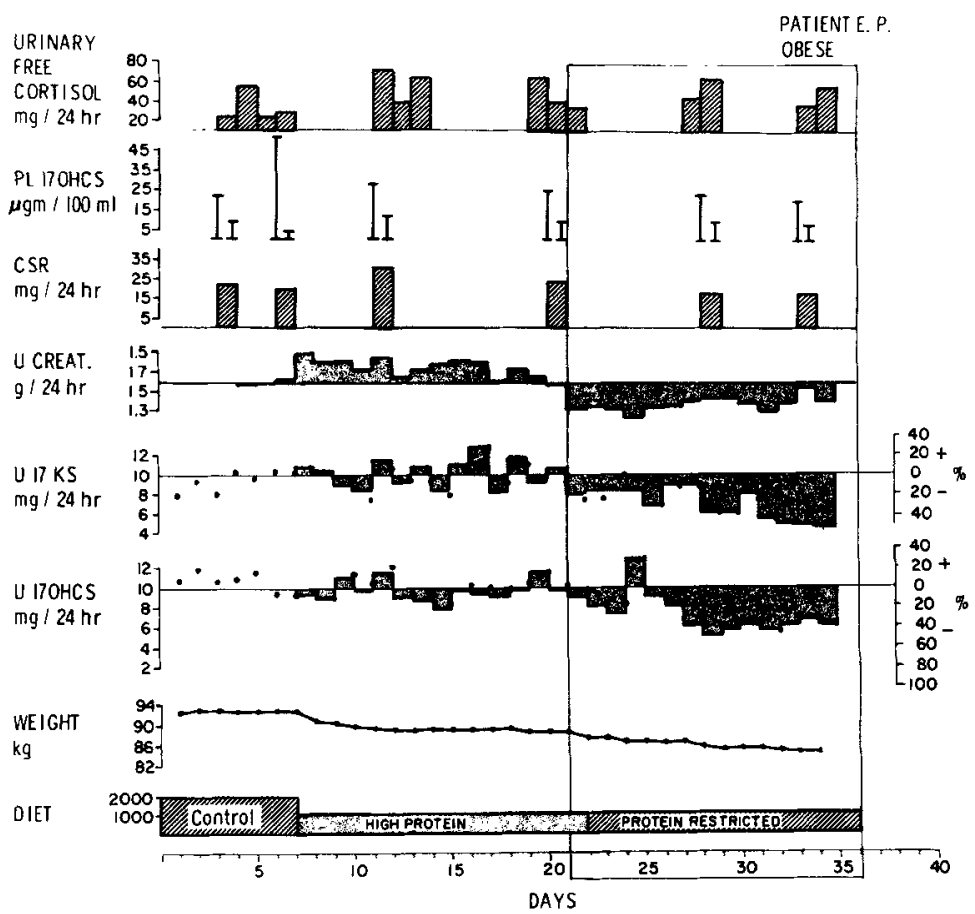

FIGURE 3. Study of the effect of protein and calorie restriction on an obese subject (E.P.). The high protein diet preceded the one low in protein.

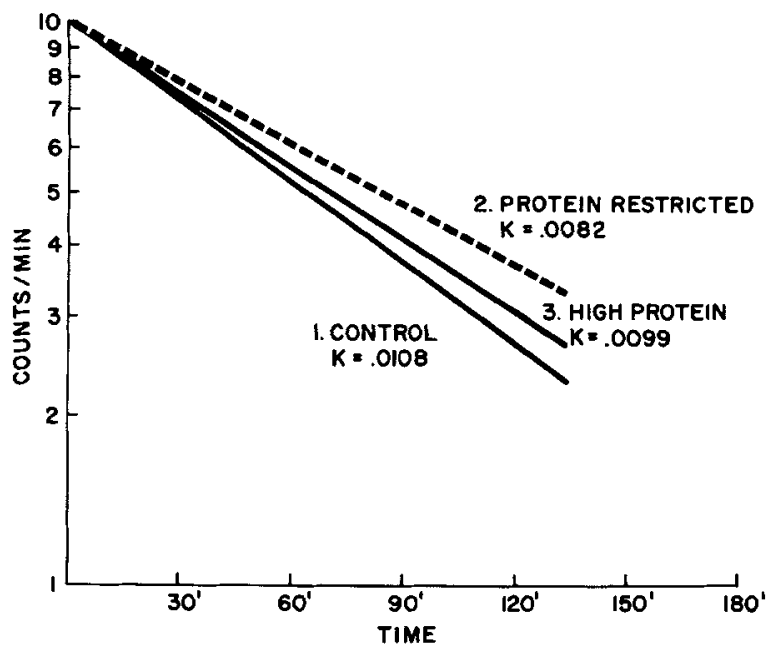

FIGURE 4. Change in cortisol turnover rate as influenced by diet (obese subject E.P.). 


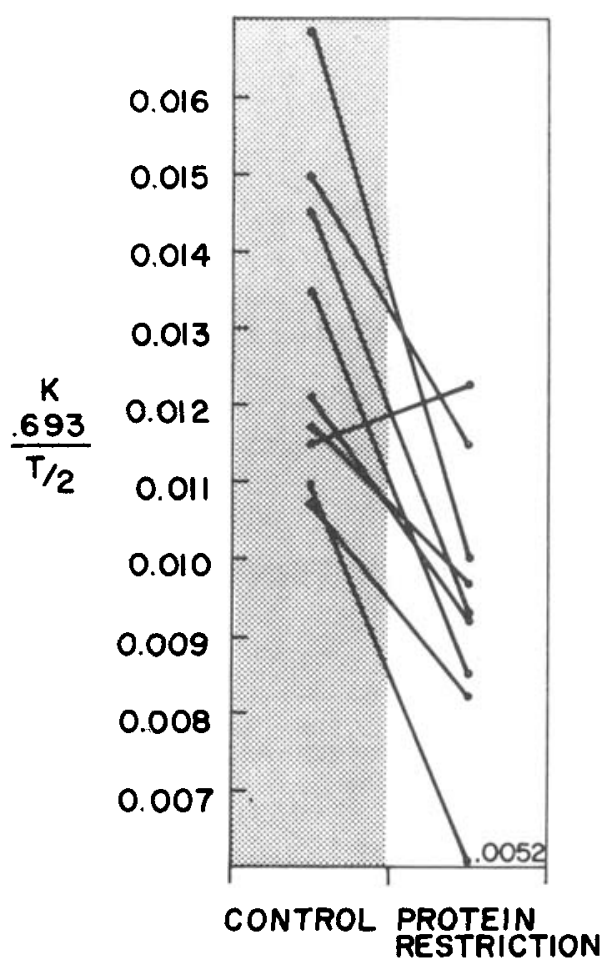

FIGURE 5. Cortisol turnover rates-effect of protein restriction.

The per cent decrease in urinary $17-\mathrm{OHCS}, 17-\mathrm{KS}$, and creatinine, CSR and $T R$ on protein restriction was related to the corresponding median levels on the control diet; that is, the higher the baseline value, the greater was the percentage decrease of each of these values (TABLE 2).

In all of the obese patients studied, urinary $17-\mathrm{OHCS}$ and $17-\mathrm{KS}$ began to decrease on protein restriction within 24 hours, although the mean maximal decrease occurred in 9.4 days $(\mathrm{SD} \pm 4.5)$ for the urinary $17-\mathrm{OHCS}$ and 12.0

TABLE 2

ADRENAL CORTICAI, FUNCTION IN OBESITY: PER CENT DECREASE FROM MEDIAL BASELINE VALUES ON PROTEIN RESTRICTION

\begin{tabular}{c|c|c|c|c|c}
\hline $\begin{array}{c}\text { Median } \\
\text { Baseline }\end{array}$ & $\begin{array}{c}\mathrm{U} \mathrm{17-0 \textrm {HC }} \\
\%\end{array}$ & $\begin{array}{c}\mathrm{U} 17-\mathrm{KS} \\
\%\end{array}$ & $\begin{array}{c}\mathrm{U} \mathrm{Cr} \\
\%\end{array}$ & $\begin{array}{c}\mathrm{CSR} \\
\%\end{array}$ & $\begin{array}{c}\text { TR } \\
\%\end{array}$ \\
\hline Highest & 36 & 56.1 & 24 & 33 & 41 \\
Median & 31.7 & 32.3 & 14 & 14 & 38 \\
Lowest & 21.1 & 18.0 & 17 & 20 & 24 \\
\hline
\end{tabular}




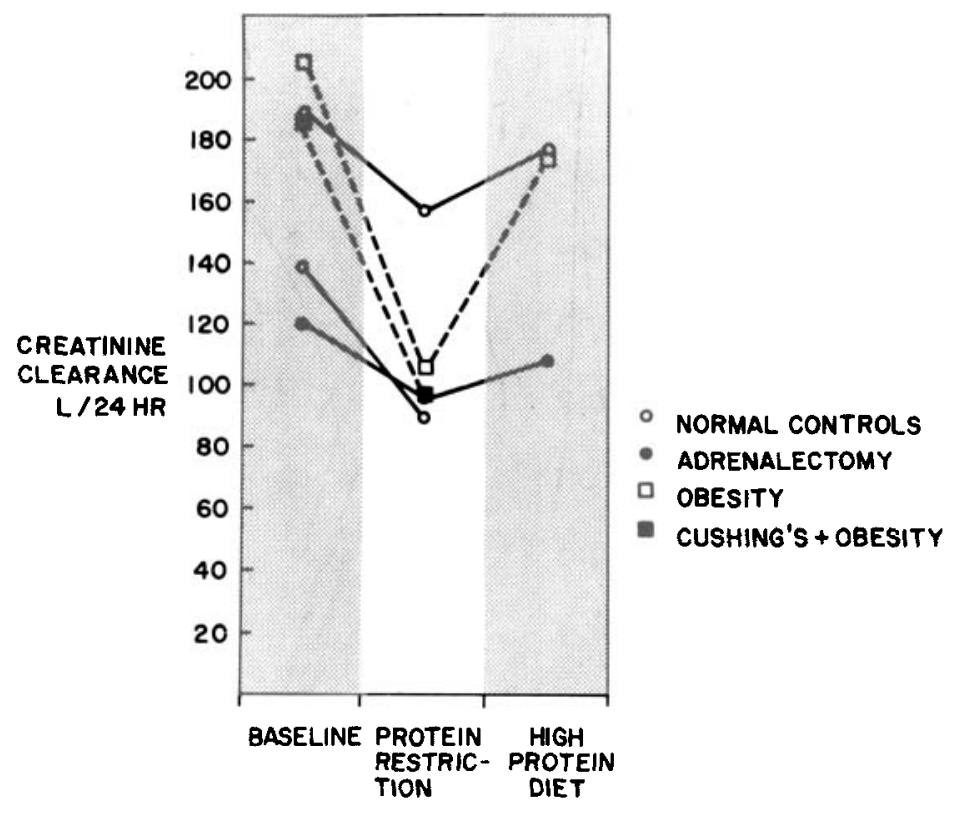

FIGURE 6. Effect of protein intake on creatinine clearance.

days $(\mathrm{SD} \pm 3.4)$ for the urinary $17-\mathrm{KS}$. The decrease in urinary creatinine followed a curve parallel to that of the urinary $17-\mathrm{OHCS}$ and $17-\mathrm{KS}$.

FIGURE 6 shows the effect of changes in protein intake upon creatinine clearance. In two obese subjects protein restriction produced a mean decrease of 51.4 per cent. This is a far greater decrease than was observed in two normal people and in one nonobese adrenalectomized patient on replacement therapy who were studied in the same way. Changes in inulin clearance in these two obese patients paralleled the changes in creatinine clearance (FIGURE 7). The decrease in urinary 17-OHCS, 17-KS, and creatinine produced by protein restriction was reversed by switching the obese subjects to a high protein intake. In most cases, however, these levels did not increase above baseline values. The speed with which they returned to baseline differed widely among the patients studied.

TABLE 3 shows how long it took for the various indices, lowered by protein restriction, to return to baseline values on a high protein intake. In some subjects urinary 17-OHCS and 17-KS returned to baseline values in 1 to 11 days. But in a large proportion of patients, urinary 17-OHCS and 17-KS and cortisol turnover rates were still below the baseline values at the conclusion of the high protein diet (14 days). Urinary creatinine returned to control levels in 1 to 12 days in all patients studied. 
TABLE 3

TIME REQUIRED FOR HIGH PROTEIN FEEDING TO REVERSE THE SUPPRESSIVE EFFECTS OF PROTEIN RESTRICTION

\begin{tabular}{c|r|c}
\hline \hline Parameter & Days & Patients \\
\hline U 17-0HCS (7) & 1 & 1 \\
& 5 & 1 \\
& 11 & 2 \\
U 17-KS (7) & 14 & 3 \\
& 11 & 1 \\
U Creatinine (5) & 14 & 6 \\
& 1 & 2 \\
& 10 & 1 \\
& 12 & 1 \\
Turnover rates (4) & $>14$ & 3 \\
\hline \hline
\end{tabular}

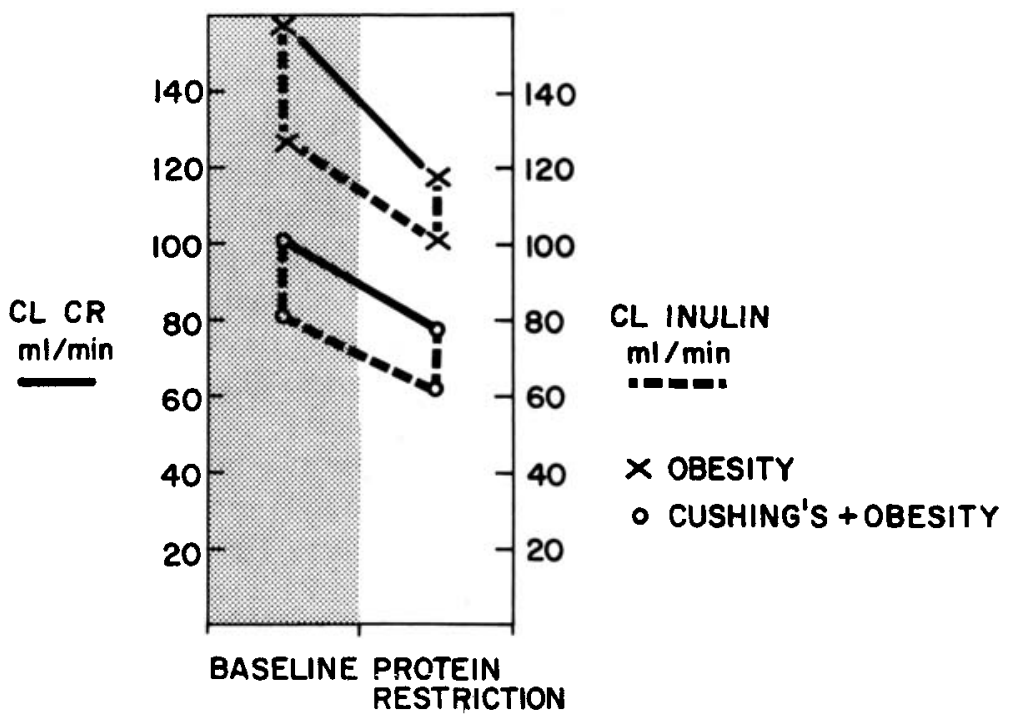

FIGURE 7. Effect of protein restriction on GFR-comparison between inulin and creatinine clearance. 


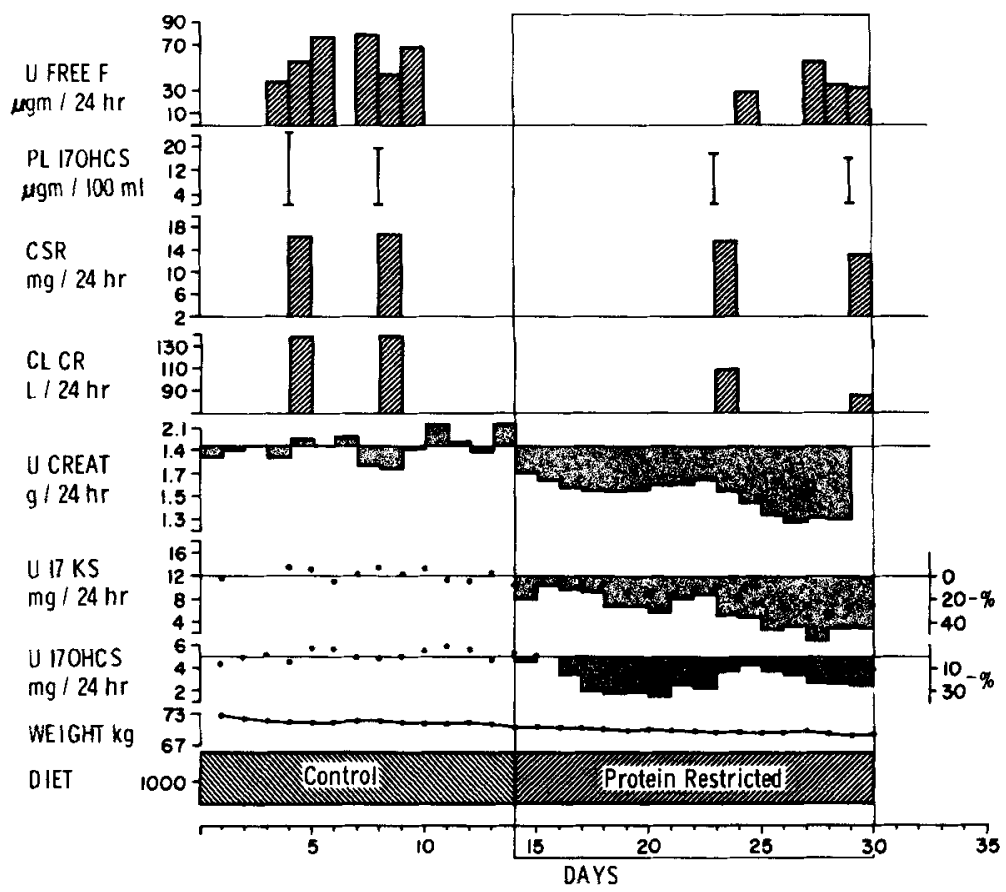

FIGURE 8. Effect of protein restriction without restriction of calories (normal subject M.G.)

\section{Effect of Protein Restriction without Restriction of Calories}

Since the decrease in cortisol secretion and the associated changes in its metabolism occur with low but not with high protein intake, despite similar caloric restriction in both cases, protein rather than calories is the important factor. This is further supported by studies carried out in two normal subjects who received maintenance calories and exhibited no significant weight loss. On protein restriction, the findings were similar to those described in the obese patients with restriction of protein and calories. The one exception was that cortisol turnover rates did not change consistently.

FIGURE 8 describes the results in one of these two normal subjects. He was studied on an average diet for 14 days followed by a protein restricted but isocaloric diet for 16 days. His weight did not change. Urinary 17-OHCS, 17$\mathrm{KS}$, and creatinine all decreased beginning within 24 hours. A maximal decrease in urinary 17-OHCS (35 per cent) occurred in seven days; in urinary $17-\mathrm{KS}$ ( 55 per cent) in 14 days and in urinary creatinine in 13 days. Creatinine clearance decreased markedly from 138 to $85 \mathrm{~L}$ per 24 hours, on protein restriction. Also decreased, although to a lesser degree were: CSR (from a mean of $16.5 \mathrm{mgm}$. per 24 hours to $13 \mathrm{mgm}$. per 24 hours) and plasma 17-OHCS (from 
a mean of $24 \mu \mathrm{gm}$. per $100 \mathrm{ml}$. to $15 \mu \mathrm{gm}$. per $100 \mathrm{ml}$.). Urinary free cortisol, although slightly lower, showed no consistent decrease on protein restriction.

To rule out an effect of protein restriction on the adrenal itself, two totally adrenalectomized patients were studied. The adrenalectomies had been performed for the treatment of Cushing's Syndrome and the patients were treated adequately with hydrocortisone and 9- $\alpha$-fluorohydrocortisone. Completeness of gastrointestinal absorption of the administered dose of hydrocortisone was confirmed by determining the "CSR." One of the patients was obese and was studied under conditions of restriction of calories similar to those of the other obese subjects described. The second adrenalectomized patient was of normal weight and was given weight maintaining diets. The results produced by protein restriction were the same as those already described.

\section{Effect of High Protein, Calorie Restricted Diets}

To determine whether a high protein intake results in increased adrenal cortical function, three obese subjects received the high protein diet prior to protein restriction. FIGURE 9 shows the results of a study in one of them. Weight declined from $117 \mathrm{~kg}$. to $108 \mathrm{~kg}$. on caloric restriction. Mean baseline

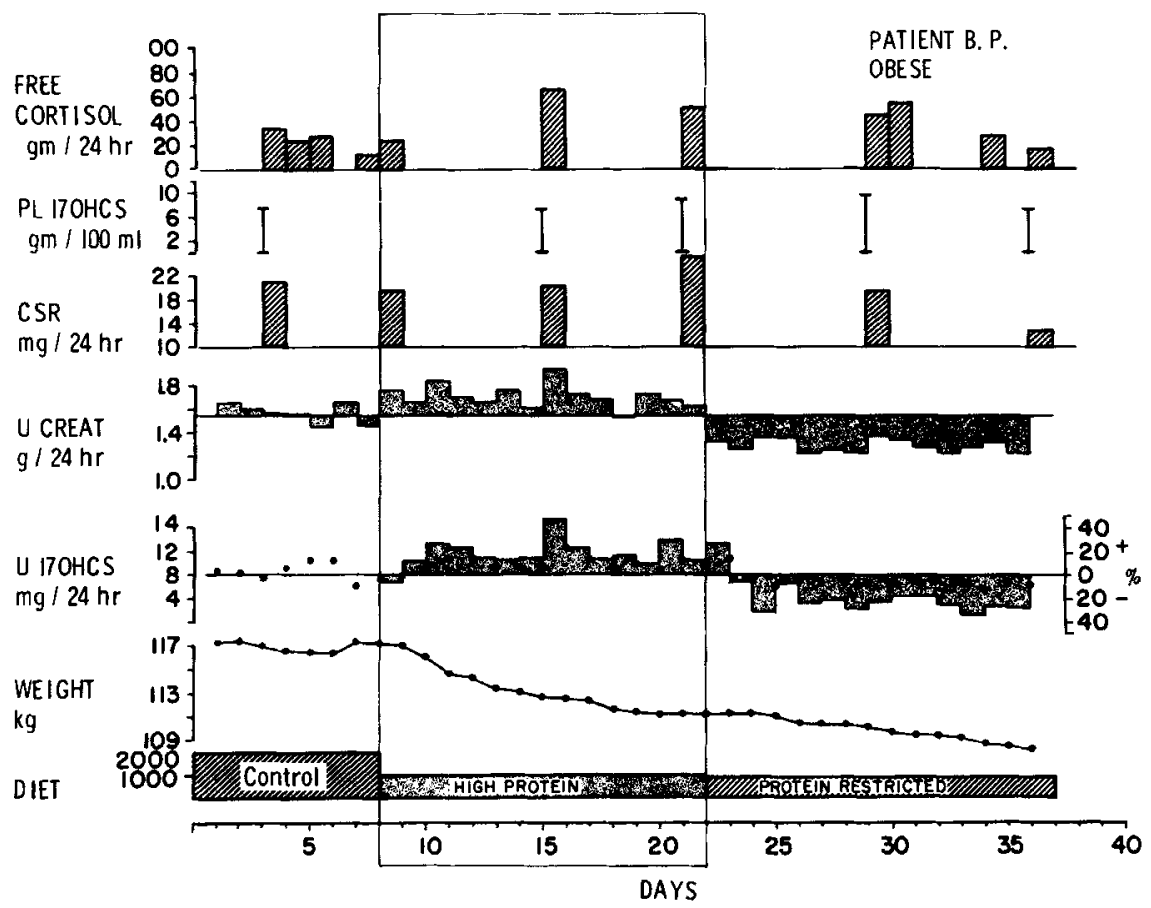

FIGURE 9. Effect of high protein, calorie restricted diet (obese subject B.P.) 
urinary 17-OHCS (8.6 mgm. per 24 hours) was high normal; mean baseline urinary 17 -KS (7.2 mgm. per 24 hours) was normal, as was the CSR (19.5 mgm. per 24 hours). Plasma 17-OHCS (6.6 $\mu \mathrm{gm}$. per $100 \mathrm{ml}$.) was low. On a high protein intake urinary 17 -OHCS increased, beginning on the second day and reached a peak on the 8 th day, remaining higher than control levels throughout this period. Urinary creatinine also increased, beginning within 24 hours and reaching a maximal level also in eight days. CSR, increased from 19.6 to

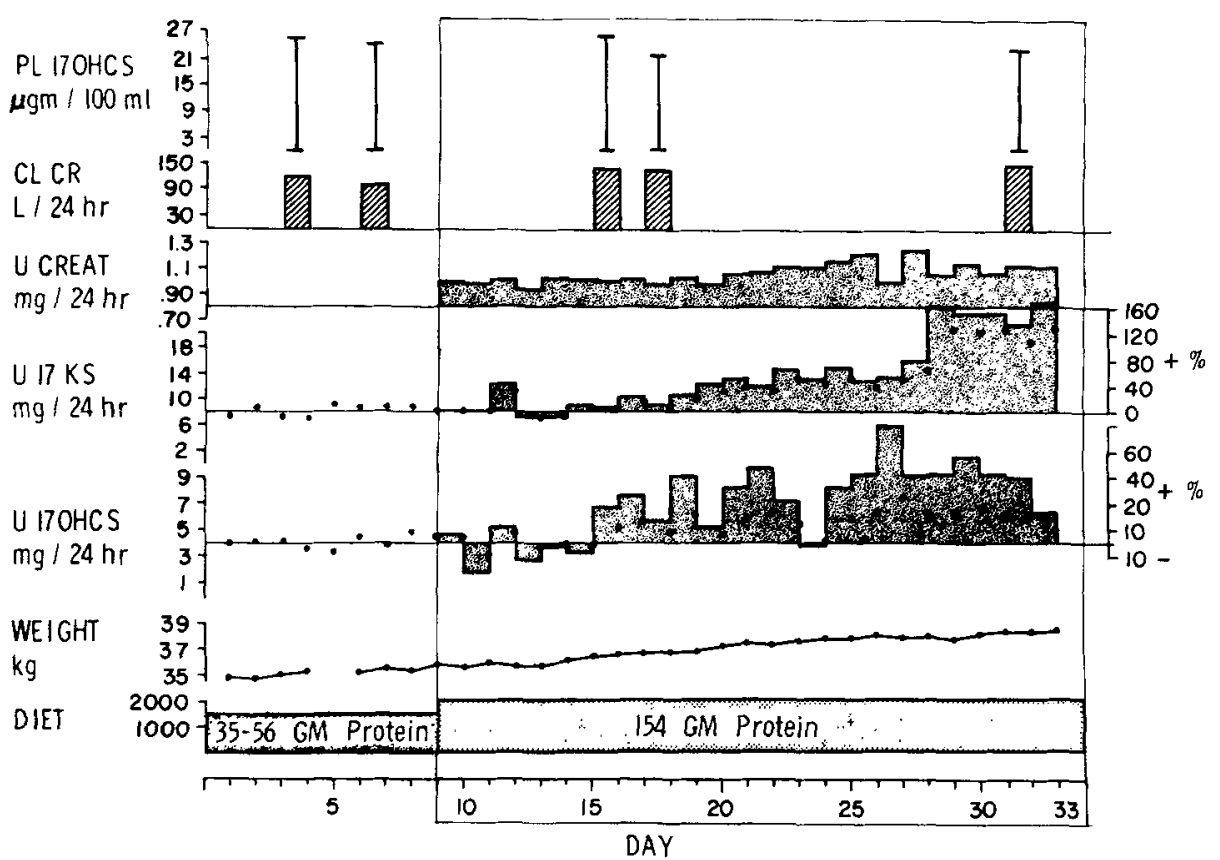

FIGURE 10. Effect of high protein intake without restriction of calories (patient with anorexia nervosa E.H.)

$25.8 \mathrm{mgm}$. per 24 hours and plasma 17-OHCS did not change. As in the data presented earlier, protein restriction at this time again resulted in a decrease in urinary 17-OHCS (maximal 34 per cent); urinary creatinine and CSR (to $12.8 \mathrm{mgm}$. per 24 hours). Plasma $17-$ OHCS remained unchanged. Urinary free cortisol levels were slightly higher on high protein intake.

\section{Effect of High Protein Intake Without Restriction of Calories}

A malnourished patient with anorexia nervosa was studied on an ad lib and on a high protein diet. FIGURE 10 shows the results of this study. During the baseline period which lasted nine days, the patient was allowed to choose her own meals. The daily amount and composition of the food ingested was deter- 
mined and found to be 35-56 grams of protein and 1400 to 1600 calories. On this diet the weight ranged from 35.0 to $35.8 \mathrm{~kg}$. The mean urinary $17-\mathrm{OHCS}$ was $4.1 \mathrm{mgm}$. per 24 hours and the mean urinary $17-\mathrm{KS}, 8.0 \mathrm{mgm}$. per 24 hours. The urinary creatinine was low, and endogenous creatinine clearance 121 and $100 \mathrm{~L}$ per 24 hours. A diet, containing 154 grams of protein, and 2000 calories was then fed to the subject for 23 days. Weight increased to $38.5 \mathrm{~kg}$. Urinary creatinine increased during the first 24 hours and continued to increase throughout the period. Creatinine clearance also increased to $150 \mathrm{~L}$ per 24 hours. Both U17-OHCS and 17-KS increased beginning seven days after the institution of the high protein diet and continued to rise until the conclusion of the study. Maximal increase in urinary $17-\mathrm{OHCS}$ was 80 per cent and in urinary 17 -KS 160 per cent.

\section{Discussion}

Tepperman, et al. ${ }^{7}$ have reported that conditions associated with rapid and excessive protein catabolism as well as increased intake of protein are associated with adrenal cortical hypertrophy. Animals fed a high protein diet ( 55 per cent protein calories) for four to seven weeks showed a 40 to 50 per cent increase in size as compared to control animals fed a smaller amount of protein. ${ }^{8}$ Conversely, Miller, et al. ${ }^{9}$ and Landau, et al. ${ }^{10}$ showed, in man, low urinary 17-ketosteroids in conditions associated with decreased food intake. Huseby, et al.," ${ }^{11}$ studied the effect of decreased food intake on adrenal cortical function of normal volunteers. They demonstrated a fall in urinary 17-OHCS and 17-KS without any significant change in the level of plasma 17-OHCS. Normal food intake restored normal urinary values. Herbst, et al. ${ }^{12}$ showed a rapid decrease in the activity of the hepatic enzyme $\Delta 4-3$ ketosteroid hydrogenase and of the turnover rates of corticosterone in rats fasted overnight. They also indicated that the activity of this hepatic enzyme varied widely with food intake.

For many years it has been known that the level of protein intake influences significantly the glomerular filtration rate (GFR). The magnitude of this effect depends on the animal species studied. Joliffe, et al., ${ }^{13}$ and Shannon, et al. ${ }^{14}$ demonstrated a decrease in urea and creatinine clearance in dogs whether fasted or fed a diet low in protein. A 3.5 fold increase in xylose and sucrose clearance was produced by feeding a meat diet. This effect persisted for as long as the high protein diet was fed. The change in GFR on various levels of protein intake has been shown to be related to variations in renal blood flow. ${ }^{15}$

In man, Cope ${ }^{16}$ has shown as much as a 40 per cent decrease in urea clearance of normal subjects when protein intake was reduced from 75 to 40 grams per day. However, an increase of protein intake from 75 to 120 grams per day produced inconsistent change. Longley, et al., ${ }^{17}$ reported an increase as high as 20 per cent in maximum urea and inulin clearance of normal subjects in 


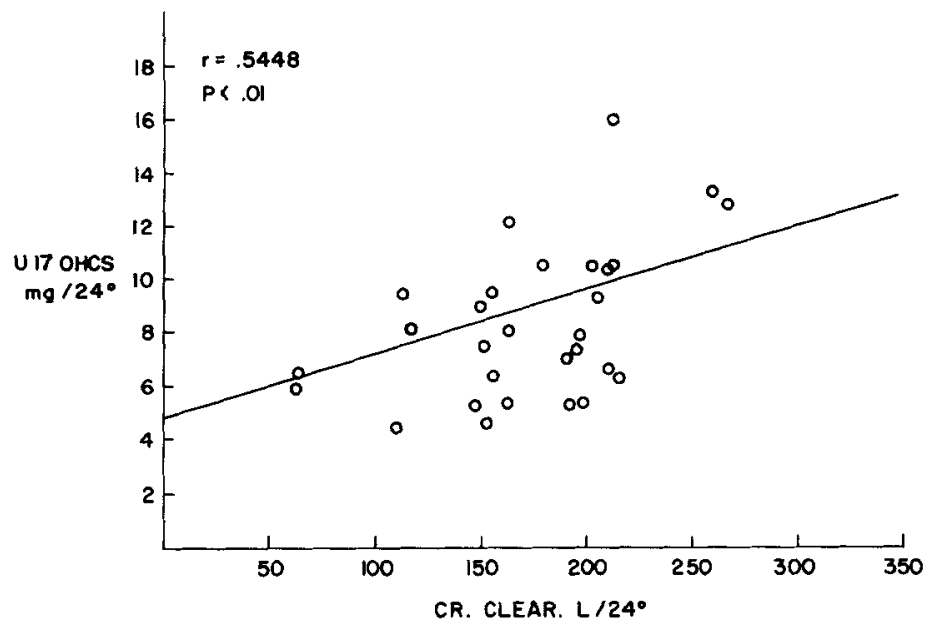

FIGURE 11. Positive correlation between urinary 17 -hydroxycorticosteroids and creatinine clearance in obesity.

nitrogen balance when dietary protein was increased from 0.3 to 2.4 $\mathrm{mg} . / \mathrm{kg}$./day.

Farr ${ }^{18}$ found that nephrotic children fed four grams of protein $/ \mathrm{kg}$. $/$ day increased urea and creatinine clearance rates to 216 per cent of normal.

Our studies on renal clearance values confirm those of others; that GFR varies directly with protein intake. In addition, we find a direct correlation

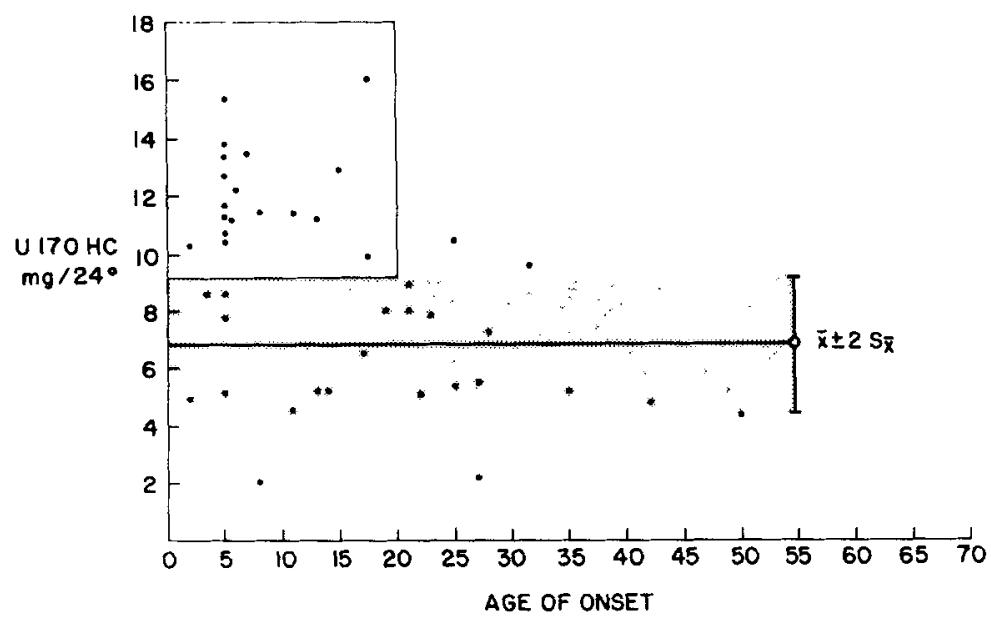

FIGURE 12. Relationship between increased urinary 17-hydroxycorticosteroids and age of onset of obesity. 
between creatinine clearance and excretion of cortisol metabolites as the protein intake of the diet is changed from high to low or low to high. Englert et al. ${ }^{19}$ have suggested that the diminished excretion of cortisol metabolites observed in renal disease with diminished creatinine clearance leads to the retention of these metabolites in the body. Elevated levels of conjugated 17 . OHCS have been measured in the plasma of such patients. They concluded that the elevated level of cortisol metabolites decreases the turnover rate of cortisol by a "mass action" on the liver, where the enzymatic reduction of cortisol takes place. A similar chain of events may be caused by protein restriction, since this also decreases creatinine clearance. By the same reasoning, increased rate of glomerular filtration produced by high protein intake would be expected ultimately to increase cortisol secretion rate. Our findings in obese patients and one patient with anorexia nervosa who were fed high protein diets not preceded by protein free diets indicate that high protein feeding does increase CSR.

It seems likely that those obese patients who exhibit increased adrenal cortical function are the high protein eaters. Since high protein intake increases GFR, we have plotted creatinine clearance against urinary 17-OHCS in 29 obese people (FIGURE 11). One notes a positive correlation between creatinine clearance and urinary $17-\mathrm{OHCS}$ with $\mathbf{r}=0.5448$, significantly different from 0 with $\mathrm{p}<0.01$.

FIGURE 12 shows an interesting relationship between urinary 17-OHCS levels observed in obese patients and the age of onset of their obesity. Seventeen ( 65.3 per cent) of 26 patients who developed obesity before age 20 had elevated urinary 17-OHCS but only two (16.2 per cent) of 12 patients who developed obesity after age 20 showed this finding. The implications of this phenomenon are being studied. However, since high protein intake seems to increase GFR more effectively in children ${ }^{18}$ than in adults, ${ }^{17}$ it is possible that onset of protein overfeeding at an early age may ultimately produce high GFR and increased clearance of cortisol metabolites.

\section{CONCLUSIONS}

1. Evidence is presented that the decreased secretion of cortisol observed in undernutrition results from restriction of protein rather than calories.

2. Protein restriction decreases GFR and diminished the clearance of cortisol metabolites. This results in a chain of events which probably is responsible for diminishing the cortisol secretion rate.

3. Such changes in adrenal cortical function are observed in both obese and nonobese subjects on protein restriction.

4. The effect of protein restriction is greater in those individuals with elevated baseline adrenal cortical function.

5. Protein overfeeding produces increases in glomerular filtration rate and in the excretion of cortisol metabolites. 
6. It is suggested that chronic protein overfeeding, when it begins particularly in youth may explain the increased adrenal cortical function observed in many obese people.

\section{ACKNOWLEDGMENT}

We wish to acknowledge the technical assistance of Joyce Roth, Joan Sobieski and David Mathews, and the help of Dr. M. A. Schork in the statistical analysis of the data.

\section{REFERENCES}

1. SCHTEINGART, D. E., R. I. GREGERMAN \& J. W. CONN. 1963. A comparison of the characteristics of increased adrenocortical function in obesity and Cushing's syndrome. Metabolism 12: 484.

2. MIGEON, C. J., D. C. GREEN \& J. P. ECKERT. 1963. Study of adrenocortical function in obesity. Metabolism 12: 718.

3. DUNKELMAN, S. S., B. FAIRHURST, J. PLAGER \& C. WATERHoUSE, 1964. Cortisol metabolism in obesity. J. Clin. Endo. Metab. 24: 832.

4. PORTER, R. H. \& C. C. SILBER. 1954. The determination of 17, 21 dihydroxy 20ketosteroids in urine and plasma. J. Biol. Chem. 210: 923.

5. CHANEY, A. L. 1958. Standard 17-ketosteroids; in Urine Methods of Clinical Chemistry. Academic Press, Inc. 2: 79-85.

6. PETERSON, R. E., A. KARRER \& S. L. GUERRA. 1957. Evaluation of Silber Porter procedure for determination of plasma hydrocortisone. Ann. Chem. 29: 144 .

7. TEPPERMAN, J., F. L. ENGEL \& C. N. H. LONG. 1943. A review of adrenal cortical hypertrophy. Endocrinology. 32: 403.

8. TEPPERMAN, J., F. L. ENGEL \& C. N. H. LONG. 1943. Effect of High Protein Diets on Size and Activity of the Adrenal Cortex in the Albino Rat. Endocrinology, 32: 403.

9. MILLER, E. V. O., O. MICKELSEN \& A. KEYS. 1948. Urinary excretion of 17ketosteroids by normal young men during starvation. Proc. Soc. Exptl. Biol. Med. 67: 288.

10. LANDAU, R. L., K. KNOWLTON, D. ANDERSON, M. BRANDT \& A. T. KENYON. 1948. J. Clin. Endo. 8: 133.

11. HUSEBY, R. A., F. C. REED \& T. E. SMITH. 1959. Effects of semistarvation and water deprivation on adrenal cortical function and corticosteroid metabolism. J. Appl. Physiol. 14: 31 .

12. HERBST, A. L., F. E. YATES, D. W. GLENISTER \& J. URQUHART. 1960. Variations in hepatic inactivation of corticosterone with changes in food intake: An explanation of impaired corticosteroid metabolism following noxious stimuli. Endocrinology 67: 222 .

13. JOLLIFFE, N.\& H. W. SMITH. 1931. The excretion of urine in the dog. II. The urea and creatinine clearance on a cracker meal diet. Am. J. Physiol. 99: 101.

14. SHANNON, J. A., N. JOLLIFFE \& H. W. SMITH. 1932. The excretion of urine in the dog. IV. The effect of maintenance diet, feeding, etc., upon the quantity of glomerular filtrate. Am. J. Physiol. 101: 625 .

15. VAN SLYKE, D. D., C. P. RHOADS, A. HILLER \& A. ALVING. 1934-35. The relationship of the urea clearance to the renal blood flow. Am. J. Physiol. 110: 387.

16. COPE, C. L. 1933. Studies of urea excretion. The effects on the urea clearance of changes in protein and salt content of the diet. J. Clin. Invest. 12: 567.

17. LONGLEY, L. P.\& M. MILLER. 1942. The effect of diet and meals on the maximum urea clearance. Am. J. Med. Sci, 203: 253. 
18. FARR, L. E. 1936. The effect of dietary protein on the urea clearance of children with nephrosis. J. Clin. Invest. 15: 703.

19. ENGLERT, E., H. BROWN, D. G. WILLARDSON, S. WALLACH \& E. L. SIMONS. 1958. Metabolism of free and conjugated 17-hydroxycorticosteroids in subjects with uremia. J. Clin. Endocrin. 18: 36. 